\title{
A 160 ÉVES MAGYAR BÖLCSŐDE TÖRTÉNETE - HOGYAN ALAKULT KI A JELENKORI BÖLCSŐDEI MÜVÉSZETI NEVELÉS? MOLNÁR RÉKA
}

az Eötvös Loránd Tudományegyetem Pedagógiai és Pszichológiai Karának hallgatója rekabalko@gmail.com

2009-től Magyarországon, főiskolai szinten tanulhatnak a bölcsődei kisgyermeknevelők, amelynek hatalmas jelentősége van Magyarországon. 2010-ben a csecsemö- és kisgyermeknevelö képzés fejlesztésére tantárgyfejlesztő csoportokat hozott létre a Csecsemő-és kisgyermekgondozó alapszak Országos Programfejlesztő Bizottsága. A tantárgyfejlesztő csoport tagjai Magyarország több felsőoktatási intézményében és bölcsődéjében oktatják a kisgyermeknevelő hallgatókat arra, hogyan érdemes kreatív játékokat játszani a bölcsődés korosztályú gyermekekkel. A Programfejlesztő Bizottság megbízásából a tantárgyfejlesztő csoport együttmüködésével kezdhette el Gyöngy Kinga annak a 2014-ben megjelent kötetnek az írását, amely egy olyan összefoglaló képet mutat a hazai bölcsődei ellátás múltjáról és jelenéröl, amelyre eddig még nem volt példa. Írásom $A$ bölcsődei müvészeti nevelés elözményei és jelen gyakorlata címü kötet két tanulmányának a struktúrájáról, tartalmáról és annak elemzéséről szól. A könyv két fejezetből áll, amelyeket Gyöngy Kinga pszichológus írt, aki az ELTE Pszichológiai Doktori Iskola doktorandusza. Az első fejezet két részre tagozódik, amelynek első része a 160 éves bölcsőde történetét mutatja be, a második rész a bölcsődei müvészeti nevelés múltját ismerteti. A második fejezet a jelenkori bölcsődei müvészeti neveléssel kapcsolatos kutatást szemlélteti, amelynek érdekes, nem várt eredményei születtek.

A kötet egyik célja, hogy a kisgyermeknevelő képzésbe bekapcsolódók számára széleskörü képet adjon a bölcsődei ellátás történetéröl. Ez azért fontos, mert megmutatja azokat a most is használt módszereket, amelyeket próbáltak már alkalmazni elődeink a magyar kisgyermeknevelésben. A kutatás másik célja, hogy választ adjon arra, milyen mértékü felnőtt közremüködésre van szükség a művészeti nevelés terén. A kötet további célja, hogy a benne foglalt nevelési elveket a kisgyermekkel foglalkozó pedagógusok megismerjék, mert ezeket ők valósítják meg a gyakorlatban. Tudnunk kell, hogy mely módszerek müködnek a gyakorlatban és melyek azok, amelyeken változtatni kell. Ennek a tudata és a pozitív változás magasabb színvonalú gondozást-nevelést teszt lehetővé a bölcsődékben. A szerző tudatosan egymásra épülve dolgozta ki a témákat, amelyre a tartalomjegyzék szolgál bizonyítékként. A kötet tartalomjegyzéke is tükrözi az elméleti alapokra épülő gyakorlati vizsgálódás jelentőségét, így tehát míg az első fejezet első része (13-38. oldalig) a 160 éves bölcsőde történetét vizsgálja, addig a második rész (45-56. oldalig) egy több évtizedes müvészeti nevelés különböző ágaiban bekövetkező 
módszertani változásokat bemutató kutatás. A második fejezet (59-127. oldalig) egy országos bölcsődei kérdőívezés eredményeit tartalmazza és rávilágít arra, hogy hogyan zajlik a gyakorlatban a gyermekek müvészetekkel való megismertetése.

A kötet első fejezete (,,A bölcsődepedagógia története a játékirányitási elvek és a müvészeti nevelés szempontjából") abból a szempontból is különleges, hogy nehezen fellelhető szakirodalmak szövegére támaszkodik. A szerző a gondozónöképzés egykori tankönyveit, minisztériumi rendeleteket, módszertani leveleket, bölcsődei ankétok és kongresszusok előadásainak tanulmányköteteit, módszertani bölcsődék értekezleteiröl származó feljegyzéseket és több nyelven íródott tudományos publikációkat elemzett, továbbá szakértőkkel, köztük Rózsa Judittal, Nyitrai Ágnessel, Németh Margittal, Kalmár Magdával és Tardos Annával készített célzott interjúkat. Az előbb felsoroltak felkutatása és felhasználása vitathatatlanul emelik a könyv színvonalát.

$\mathrm{Az}$ első fejezet első része (,Bölcsődetörténet a játékirányitás kérdésének szemszögéböl') felöleli 1852-töl egészen napjainkig a bölcsőde történetét. A szerkezetileg jól felépített rész egy olyan ívet ad a tanulmánynak, amely nem csak a múlt és a jelenkor különbségeit, de a hasonlóságokat is szemlélteti, ez segít a módszerválasztás okainak megértésében.

A szerző részletesen bemutatja, hogy mit jelentett a bölcsőde a második világháború elött. A kórházi, óvodai és a csecsemöotthoni minta című alfejezetek által ezt megismerhetjük. Megtudhatjuk, hogyan váltotta fel a párhuzamos napirendet a folyamatos napirend, az irányított játékot a szabad játék elve és hogyan jutottunk el a nyitott bölcsődéig.

A szerző nemzetközi összehasonlító vizsgálatot is végzett, azaz Magyarország és Kelet-Németország bölcsődéiben használt nevelési elveket hasonlította össze. 1983-ban hazánkban a szabad játék elve uralkodott, addig Kelet-Németországban a játékirányítás volt a hangsúlyos. Az akkor készült fejlődési tesztek eredményei a magyar gyermekeknél jobbak lettek a német gyermekekénél. Az eredmények mentén megtudhatjuk a magyar-német pedagógiai összehasonlító vizsgálat tanulságait: szükségtelen az erőltetett fejlesztés, ha a gyermek számára ingergazdag, biztonságos környezetet biztosítunk.

A bölcsődetörténet témában megjelent szakirodalmakat jól összefoglalja a kötet. Gyöngy Kinga a bölcsődetörténet kronológiáját Vokony Éva 2002-ben megjelent Kis magyar bölcsődetörténet címú írása alapján mutatja be. A bölcsődetörténeti kutatás megkövetelte továbbá olyan kulcsfontosságú szakemberek munkájának az ismeretét, mint Pikler Emmi, Tardos Anna, Polónyi Erzsébet, Majoros Mária és Nyitrai Ágnes. Pikler Emmi 1972-ben kiadott Az egészséges csecsemő és gyermek fejlődése és gondozása című három kötetes könyve nélkülözhetetlen alapot szolgálnak ahhoz, hogy megértsük a Pikler-pedagógiát. Pikler kiemeli a gondozás minőségének fontosságát, amely befolyásolja a gyermek viselkedésének alakulását. A második kötet mutatja meg a csecsemő és kisgyermek gondozásának az alapkövetelményeit az intézményekben. Ez jó alapul szolgált a 
szerző számára a második világháború utáni kisgyermekgondozás megismeréséhez, annak bemutatásához.

A fejezetben megismerhetjük Pikler Emmi Lóczy úti csecsemőotthonát, és az ott kidolgozott módszereket. Ez a korszak mérföldkő a kisgyermekgondozás területén, hiszen Pikler saját koncepciót dolgozott ki a személyes jellegü csecsemőgondozás minden területére.

A fejezet egymással szembefordítja Pikler és a Bölcsődék Országos Módszertani Intézet álláspontját. Míg a Pikler a játék gyermekek által választott formáit támogatja, addig a BOMI a rendszerváltás utáni években a felnőtt játékban való részvételét részesíti előnyben. A Csecsemőotthonok Országos Módszertani Intézménye és a Bölcsődék Országos Módszertani Intézménye által ellátott gyermekek különböző helyzete (csecsemőotthon és családban nevelődés) magyarázza az eltérő álláspontot.

A pedagógiatörténeti kutatás során a szerző eljut az 1997-ben írt „Játék a bölcsődében" című módszertani levélhez, amelyből megismerhetjük a bölcsődei játékok alapelveit, a különböző játékelméleteket, a játék definícióját és funkcióit, továbbá a gondozónő szerepét a játéktevékenységben. A módszertani levél és a Lóczyban dolgozó szakemberek korábbi tankönyvei között már találunk szemléletbeli hasonlóságot, például a játékfejlődés ismertetése életkori bontásban vagy a játékkészlet. Az első rész végén található összefoglaló táblázat jól illusztrálja a különböző korszakok játéksegítési módszereit, ez az olvasó számára segíti a megértést. Az első fejezet második része (,A müvészeti nevelés módszertanának változása a különbözö nevelési felfogások hatására”) azt vizsgálja, hogyan változott a művészeti nevelés az évtizedek alatt. A szerző a művészeti nevelést különböző formákra bontotta le: anyanyelvi nevelés (mesélés, versmondás, mondókázás, bábozás), ének-zenei nevelés (ének), vizuális nevelés (plasztikázás, firka és rajz). A kötet az 1950-es évek végétől követi végig, hogyan fejlödött az a tapasztalat, amely alapján kibontakoztak a bölcsődei müvészeti nevelés elvei. Ez a rész világosan bemutatja, hogy a müvészeti nevelés múltbéli és a jelenkori gyakorlata közötti különbséget tetten érhetjük abban, ahogyan az eszközöket használták, vagy a felnőtt tevékenységének céljában, például abban, hogy rajzolásra a folyamat megtapasztaltatásáért vagy az eredmény kedvéért teremtünk lehetöséget.

A kötet második fejezete Egy országos kutatás tanulságai a bölcsődei müvészeti nevelésről címet viseli. A bölcsődei szakemberek, pedagógusok számára a bemutatott eredmények azért tanulságosak, mert képet adnak a kisgyermeknevelő szakma jellemzőiről és segítséget nyújtanak a kisgyermeknevelők gyakorlatának reflektáláshoz. A kérdőíves adatfelvételre 2011. február és május között került sor. A szerző bölcsődékben és egységes óvoda-bölcsődékben dolgozó kisgyermeknevelöket keresett meg a kérdőívvel, amelyeket elektronikus úton küldött és hólabda módszerrel indította el a kérdőívfelvételt. A kérdőív nyílt és zárt végü kérdéseket tartalmazott. OÖsszesen 921 kérdőív érkezett vissza, a szerzőnek a teljes populáció 13,9\%-át sikerült elérnie. Az 1982-es Ferenczy és munkatársai 
még arra az eredményre jutottak, hogy a kisgyermeknevelő szakmában a fiatalok vannak többségben. A 2000-es Szele Béláné Debrecen város önkormányzati fenntartású bölcsődéiben dolgozó kisgyermeknevelőivel készített interjú eredményei egyértelmúen tükrözi, hogy feltünően alacsony a fiatalok aránya. Évtizedekre visszamenőleg a korábbi vizsgálatokat és a saját kutatásának eredményeit is figyelembe véve a szerző arra a következtetésre jutott, hogy a kisgyermeknevelő szakma elöregszik, ennek okait több oldalon keresztül boncolgatja. A szerző hangsúlyozza, hogy nem teljes körü lekérdezéssel állunk szembe, tehát nem szabad túlzott következtetésekbe bocsátkozni.

A szerző az adattömeget diagramokkal, táblázatokkal szemlélteti, ami átláthatóvá teszi a müvészeti nevelés különböző területeinek müködését. A gyakorlatban megjelenő müvészeti nevelés formáihoz kapcsolódó és azokat szemléltető képek még élvezetesebbé teszik az olvasást. Kiemelkedő jelentőségü, hogy a szerző a múvészeti nevelés módszertanilag vitás kérdéseivel kapcsolatban is gyüjtött információkat, ami azt jelenti, hogy a kérdőív minden logikailag lehetséges helyzetre rákérdezett, olyanokra is, amely ellentétes a módszertani ajánlásokkal. Ilyen vitás kérdés például a gondozási helyzetben lévő éneklés, mondókázás. A szerző célja ezzel az volt, hogy tisztán lássa a gyakorlatban folyó nevelés mikéntjét, és amely alapot szolgálhat a jövőbeni módszertani ajánlások alakításában.

Sok olvasó lepődhet meg a kapott eredményektöl. Az eredmények közül a következőket emelem ki: megdöbbentőek a kisgyermeknevelő szakma elöregedésére vonatkozó adatok. Magasabb végzettséggel rendelkeznek a fiatalok, mint az idősebb, régebb óta dolgozó kisgyermeknevelők. Túltöltöttek a bölcsődei csoportok, az életkori különbség fél és két év közt is lehet az egy csoportba járó gyermekek között. Az aktívan használt dalok, mondókák, versek száma nem túl nagy, a mintára vetítve azonban több száz változattal találkozhatunk. A szerzőt meglepte, hogy gyakori a játékos torna a bölcsődékben. A szopránfurulya használata meghatározó szerepet tölt be a hangszerek tekintetében. Nem tudatos a bölcsődékben a mesekönyv választás, a népmesékhez képest a mümese dominál. A gyurmázás gyakrabban megvalósuló alkotó tevékenység, mint a festés.

A Csecsemő-és kisgyermekgondozó alapszak Országos Programfejlesztő Bizottsága megbízásából elkészült könyv legfontosabb célkitüzése az volt, hogy a bölcsődei müvészeti nevelés országos kutatásának eredményei nyomán elkészülhessen egy ajánlás a kisgyermeknevelő képzés számára. A sikeres kutatás lehetővé tette az ajánlás elkészülését, amelyet az utolsó alfejezetben olvashatunk. A kötet mellékletében megtalálható a müvészeti nevelés kutatását szolgáló kérdőív, illetve a hazai bölcsődei adatbázis (124-151. oldalig).

A két tanulmány elektronikus formában is elérhető, azonban, aki a nyomdai példányt szeretné a kezében tartani, annak csalódást okozhat a sok apró betủ, ami megnehezíti az egyébként olvasmányos müvet. A tanulmányban mindvégig hangsúlyos a bölcsődei napközbeni ellátás fejlődése és a színvonalas bölcsődei mủvészeti nevelés gyakorlati megjelenésének jelentősége. 
A könyv tudományos jelentősége, hogy a szerző bölcsődei művészeti neveléssel foglalkozó országos kutatást végzett, amire eddig még nem volt példa, éppen ezért a szakmában alapvető münek kell, hogy számítson. A könyv tankönyvként szolgál a csecsemő- és kisgyermeknevelö hallgatók számára, de forgathatja minden bölcsődei szakember és pedagógus, illetve a kisgyermeknevelés iránt érdeklődők.

Gyöngy Kinga (2014): A bölcsődei müvészeti nevelés előzményei és jelen gyakorlata. ELTE Eötvös Kiadó, Budapest. 148 o. 